\author{
RAJNHARDT KOKOT \\ ORCID: 0000-0002-6240-7282 \\ Uniwersytet Wrocławski
}

\title{
PRZESTEPSTWO PRZYJECIA ZLECENIA ZABOJSTWA (ART. 148A § 1 K.K.) W UJĘCIU NOWELIZACJI KODEKSU KARNEGO Z 13 CZERWCA 2019 ROKU
}

\begin{abstract}
Abstrakt: Opracowanie podejmuje problematykę nowego, wprowadzonego mocą nowelizacji kodeksu karnego z 13 czerwca 2019 roku, przestępstwa odpłatnego przyjęcia zlecenia zabójstwa (art. 148a $\S 1$ k.k.). Nie ulega wątpliwości, że jest to rozwiązanie bezprecedensowe, nadające zasadzie ochrony życia i jej zakresowi zupełnie nowego znaczenia. Wyprowadza ono ochronę życia z dotychczasowych ram zachowań zabronionych chroniących to dobro, przesuwając ją na płaszczyznę zachowań, które nigdy dotąd nie były karalne, bardzo oddalonych od wystąpienia zamierzonego przez sprawcę skutku. Przestępstwo to, na co zwrócono uwagę już w toku prac nad nowelizacją ustawy karnej w licznych opiniach formułowanych przez przedstawicieli środowiska karnistycznego, budzi wiele wątpliwości, w tym takie, które wiążą się z poszanowaniem przez tę ustawową konstrukcji fundamentalnych zasad prawa karnego. Kryminalizacja zachowań na tak odległym przedpolu naruszenia dobra prawnego może być w szczególności źródłem kontrowersji w kontekście gwarancyjnej funkcji prawa karnego. Przeprowadzona analiza ma na celu zwrócenie uwagi na kilka najistotniejszych kwestii dotyczących tego przestępstwa, między innymi jego charakteru prawnego, uzasadnienia jego typizacji, konstrukcji jego ustawowych znamion, możliwych przypadków zbiegu przepisów czy przestępstw, w których może pozostawać, trudności, jakie nowa konstrukcja może nieść dla praktyki wymiaru sprawiedliwości, a także samej potrzeby wprowadzenia omawianej „modyfikacji granic” prawnokarnej ochrony życia człowieka.
\end{abstract}

Słowa kluczowe: zabójstwo, ochrona życia, zlecenie, korzyść majątkowa, korzyść osobista, obietnica korzyści, kryminalizacja, penalizacja, nowelizacja

Wśród licznych zmian wprowadzonych mocą nowelizacji z 13 czerwca 2019 roku do części szczególnej kodeksu karnego na uwagę zasługują niewątpliwie te, które odnoszą się do przepisów chroniących życie i zdrowie człowieka. W publicznej dyskusji dotyczącej nowelizacji, jaka wywiązała się wśród komentatorów, zwłaszcza na poziomie medialnym, mimo swej rangi nie były one jednak szcze- 
gólnie eksponowane. Fala zainteresowania skoncentrowała się bowiem na „nowej odsłonie" przepisów regulujących zwalczanie przestępczości przeciwko wolności, zwłaszcza o charakterze pedofilskim. Zmiany dotyczące tej części zmodyfikowanych przepisów prawa karnego tak wyraźnie zdominowały toczące się wokół nowelizacji spory, iż mniej wprawny obserwator mógł wręcz odnieść wrażenie, że są to jedyne, a w każdym razie najistotniejsze i najdalej idące zmiany, które wprowadzono w ustawie karnej.

W zakresie przepisów chroniących życie i zdrowie człowieka uwagę zwraca zarówno zakres, jak i radykalizm wprowadzonych „nowości”. Ich podstawowym założeniem, podobnie zresztą jak większości pozostałych modyfikacji ustawy karnej - na co wskazuje uzasadnienie projektu — było zwiększenie surowości odpowiedzialności karnej mające poprawić efektywność działania norm prawa karnego ${ }^{1}$. Zmiany realizujące ten kierunek w rozdziale XIX kodeksu karnego mają dwoisty charakter. Są to zarówno zmiany ilościowe, jak i jakościowe. Po pierwsze, nowelizacja zaostrzyła sankcje przewidziane za niektóre przestępstwa przeciwko życiu i zdrowiu, podnosząc granice ustawowego zagrożenia między innymi za zabójstwo w typie podstawowym oraz typach kwalifikowanych, nieumyślne spowodowanie śmierci, ciężki uszczerbek na zdrowiu czy udział w bójce lub pobiciu. Po drugie, wprowadziła rozwiązania prawne niewystępujące dotąd w ustawie karnej, w tym nowe typy przestępstw przeciwko życiu: przyjęcie zlecenia zabójstwa (art. 148a $\S 1$ k.k.) oraz kwalifikowany typ nieumyślnego spowodowania śmierci więcej niż jednej osoby (art. $155 \S 2$ k.k.), a także nową regułę odpowiedzialności karnej za przygotowanie zabójstwa (art. 148 § 5 k.k.).

Treścią niniejszego opracowania jest analiza dodanego, zupełnie nowego na gruncie polskiego prawa karnego, typu przestępstwa przeciwko życiu, którego znamiona zostały ujęte $\mathrm{w}$ przepisie art. 148a $§ 1$ k.k. określającym przyjęcie zlecenia zabójstwa w zamian za udzieloną lub obiecaną korzyść majątkową lub osobistą, zagrożone karą pozbawienia wolności od lat 2 do 15. Mając na uwadze konstrukcję jego ustawowych znamion, przestępstwo to można określić mianem „odpłatnego przyjęcia zlecenia zabójstwa”. Przepis ten jako autonomiczną postać przestępstwa przeciwko życiu kreuje rodzaj wejścia w porozumienie między zleceniodawcą a zleceniobiorcą, którego treścią jest popełnienie zabójstwa. W ocenie projektodawcy niekryminalizowanie takich zachowań tworzyło „lukę prawną, zwłaszcza biorąc pod uwagę społeczną szkodliwość i zagrożenie karne przestępstwa zabójstwa"2. Regulacja ta miała zatem usuwać wspomniany deficyt w zakresie ochrony

1 Zaostrzenie odpowiedzialności za poszczególne przestępstwa zgodnie z tym założeniem miało być realizowane „w sposób selektywny i racjonalny, oparty na wnikliwej ocenie zasadności wzmocnienia prawnokarnej ochrony w określonych dziedzinach życia społecznego, w które prawo karne wkracza, stawiając tam ludzkim zachowaniom nieprzekraczalne granice" - uzasadnienie projektu nowelizacji kodeksu karnego — wersja z 5 kwietnia 2019 roku, s. 20, https://legislacja.rcl. gov.pl (dostęp: 20.09.2019).

2 Ibidem, s. 23. 
życia, stanowiąc jednocześnie swoisty „refleks postulatu karalności przygotowania do zabójstwa"' , czego wyrazem było także zagrożenie karą, którego granice są takie same jak w przypadku sankcji przewidzianej w art. 148 § 5 k.k. Jej walorem, w myśl tez zawartych w uzasadnieniu projektu, miało być to, że w przeciwieństwie do przygotowania zabójstwa przyjęcie zlecenia zabójstwa obejmuje także stany polegające na „chociażby milczącym” zaakceptowaniu propozycji, której treścią jest zabójstwo, co oznacza, iż można je popełnić również w formie zaniechania, niemieszczącego się w prawnych ramach przygotowania ${ }^{4}$.

Już na wstępie należy zwrócić uwagę na kontrowersje, jakie może budzić wyrażona $\mathrm{w}$ uzasadnieniu projektu nowelizacji opinia w kwestii normatywnego charakteru tego przestępstwa. Jak bowiem wprost z niego wynika, przestępstwo określone w art. 148a $\S 1$ k.k. to „nowy kwalifikowany typ czynu zabronionego”. Jak argumentuje się w rozwinięciu przywołanej tezy, wyodrębnienie takiego zachowania „w ramach oddzielnego kwalifikowanego typu przestępstwa jest uzasadnione koniecznością uwzględnienia na płaszczyźnie ustawowego wymiaru kary szczególnego natężenia stopnia społecznej szkodliwości, jaki wiąże się z projektowanym znamieniem kwalifikującym"5. W kontekście tak ujętego stanowiska trudno

3 Ibidem.

${ }^{4}$ Ibidem, s. 24. Na marginesie należy zwrócić uwagę na niefortunność tak ujętej w uzasadnieniu tezy, opartej na swoistym nieporozumieniu. Trudno bowiem zgodzić się z założeniem, iż odpłatne przyjęcie zlecenia zabójstwa w formie sprawstwa w ogóle może mieć postać zaniechania w normatywnym znaczeniu tego pojęcia. Taka sytuacja byłaby natomiast możliwa w przypadku pomocnictwa (art. $18 \S 3$ zd. 2 k.k.). Przeciwne stanowisko musiałoby się opierać na przyjęciu oczywistej skądinąd, z innej jednak perspektywy dość przewrotnej tezy, że każdy podmiot ma prawny obowiązek wyraźnego nieprzyjmowania zleceń zabójstwa. Wprawdzie taki nakaz, teoretycznie rzecz biorąc, można z przepisu wyinterpretować, co wszakże nie oznacza, iż „milczące” przyjęcie zlecenia zabójstwa stanowi popełnienie tego przestępstwa w formie zaniechania. Idąc tym tropem, należałoby przykładowo również przyjąć, że także każde zabójstwo jest przestępstwem popełnionym przez zaniechanie, skoro niewątpliwie na każdym ciąży powinność (nakaz) niezabijania innych ludzi, co oznaczałoby, iż ten, kto zabił, zaniechał tego obowiązku. Nie powinno budzić wątpliwości, że z obu unormowań należy wyprowadzić normę sankcjonowaną zakazującą określonego zachowania się, nie zaś normę nakazującą określone niezachowywanie się. W omawianym przypadku problem nie polega więc na zaniechaniu określonej powinności, lecz jedynie na nieuzewnętrznionym czy niewyartykułowanym akcie woli zabicia człowieka, związanym przyczynowo z przyjęciem korzyści lub jej obietnicy. Podjęcie takiej decyzji, mimo jej niewysłowienia, musi być oceniane jako działanie. Niemożliwe jest bowiem potraktowanie przyjęcia „celowej” korzyści lub jej obietnicy jako formy zaniechania. To, że sprawca „milcząco” przyjmuje zlecenie zabójstwa w zamian za określoną w ustawie formę korzyści lub jej obietnicę, nie oznacza wszakże wcale, iż realizuje znamiona tego przestępstwa w formie zaniechania. Nie ulega wątpliwości, że akt woli tej treści stanowi działanie, a nie zaniechanie sprawcy, a jedynie treść tej decyzji nie zostaje wyraźnie zakomunikowana zleceniodawcy. Ustawa wszakże nie wymaga wysłowienia podjęcia przez zleceniobiorcę zamiaru zabicia człowieka. Także więc taki, wolny od słów, konkludentny konsensus między stronami swoistego porozumienia, którego treścią jest zabicie człowieka, należy niewątpliwie potraktować jako wyraz działania tego, kto odpłatną propozycję zabójstwa przyjął. Zaniechane zostało jedynie poinformowanie o tym zleceniodawcy, takiego jednak wymogu — jak wcześniej wspomniano — ustawa nie formułuje.

5 Ibidem, s. 20. 
jednak dociec, w stosunku do jakiego podstawowego typu czynu zabronionego regulacja art. 148a $\S 1$ k.k. miałaby stanowić cięższą odmianę, mogącą uchodzić za jej typ kwalifikowany. W szczególności ani konstrukcja znamion tego przestępstwa, ani też sankcja, która jest za nie przewidziana, nie pozwala na przyjęcie, iż jest to kolejny, wyodrębniony w ustawie kwalifikowany typ zabójstwa w stosunku do typu podstawowego $\mathrm{z}$ art. $148 \S 1 \mathrm{k}$.k. Równie trudno byłoby przestępstwo to uznać za typ kwalifikowany narażenia życia na niebezpieczeństwo z art. 160 k.k., mimo że niewątpliwie wiąże się ono $\mathrm{z}$ wywołaniem określonego stanu niebezpieczeństwa dla tego dobra, w którym przed przyjęciem zlecenia zabójstwa dobro to się nie znajdowało. Brakuje też wszelkich podstaw, by w przestępstwie „przyjęcia zlecenia zabójstwa” dostrzegać znamiona „kwalifikowanego typu” przygotowania zabójstwa zagrożonego karą w art. 148 § 5 k.k., którego w myśl uzasadnienia projektu ma być „refleksem”.

Punktem odniesienia w „procesie” wyodrębniania typu kwalifikowanego ma być bowiem inny typ przestępstwa — zwykle podstawowy, a wyjątkowo także kwalifikowany — nie zaś karalna postać stadialna czynu zabronionego. W tym stanie rzeczy najłatwiej byłoby więc uznać przyjęcie zlecenia zabójstwa „w zamian za udzieloną lub obiecaną korzyść majątkową lub osobistą" za kwalifikowaną postać typu podstawowego „przyjęcia zlecenia zabójstwa”, a więc podjęcia zamiaru jego popełnienia, bez stosownej majątkowej lub osobistej gratyfikacji lub jej obietnicy. Rzecz w tym, iż takiego przestępstwa — ani w dotychczasowym stanie prawnym, ani po nowelizacji — kodeks karny nie typizuje. Jak z tego wynika, nie ma podstaw, by typ wyodrębniony w art. 148a § 1 k.k. traktować jako typ kwalifikowany, nie sposób bowiem wskazać typu dla niego podstawowego. Należy zatem przyjąć, że jest to autonomiczny, podstawowy typ przestępstwa, a norma sankcjonowana wynikająca $\mathrm{z}$ art. 148a $\S 1$ k.k. chroni życie człowieka równolegle z normami sankcjonowanymi dekodowanymi z innych przepisów typizujących przestępstwa przeciwko życiu wyodrębnionych w ustawie karnej, przy czym czyni to na najwcześniejszym etapie wywołania zagrożenia dla tego dobra prawnego. Ustawa nie wyróżnia przy tym jego szczególnych odmian — ani w postaci typu kwalifikowanego, ani uprzywilejowanego.

Rozwiązanie przyjęte w omawianym przepisie ma niewątpliwie bezprecedensowy charakter. Żadna z dotychczasowych kodyfikacji rodzimego prawa karnego samego ,przyjęcia zlecenia zabójstwa”, jak zresztą samego „przyjęcia zlecenia” popełnienia jakiegokolwiek innego przestępstwa, nie typizowała ${ }^{6}$. Nie można jednak

${ }^{6}$ W konstrukcji typów czynów zabronionych znamię „przyjęcia” w polskim prawie karnym łączone jest natomiast między innymi z pozyskaniem „korzyści majątkowej lub osobistej albo jej 
przeoczyć tego, że samo pojęcie „zlecenia” przestępstwa znajduje wyraz w rodzimym porządku prawnym, i to na jego najwyższych szczeblach, choć w odmiennym od analizowanego kontekście 7 . Problematyka ,przestępstw zleconych” znajdowała miejsce także w opracowaniach naukowych, zarówno o profilu kryminologicznym, jak i karnistycznym, w których zwracano uwagę na potrzebę poszukiwania nowych rozwiązań prawnych służących zwalczaniu tego zjawiska, które określano wręcz — choć chyba nieco na wyrost - „plagą naszych czasów”, pozostającą najczęściej w ścisłym związku z przestępczością zorganizowaną oraz zawodową ${ }^{8}$ Trzeba przy tym podkreślić, iż uwaga komentatorów tego zjawiska z reguły koncentrowała się na sprawcach udzielających zlecenia popełnienia przestępstwa, co wiązało się z dyskusją wokół tak zwanego sprawstwa zlecającego (zleceniodawczego) i podejmowanych na płaszczyźnie legislacyjnej prób wprowadzenia tej postaci sprawstwa niewykonawczego do rodzimego porządku prawnego9.

obietnicy” (art. 228 k.k., art. 250a § 1 k.k., art. 296a § 1 k.k., art. $302 \S 3$ k.k.), ,rzeczy uzyskanej za pomocą czynu zabronionego" (art. 291 § 1 k.k., art. 292 § 1 k.k.) lub ,środków płatniczych, instrumentów finansowych, papierów wartościowych, wartości dewizowych, praw majątkowych lub innego mienia ruchomego lub nieruchomości” (art. 299 k.k.).

7 Do przestępstw popełnianych „na zlecenie” funkcjonariuszy publicznych odwołuje się art. 44 Konstytucji RP z 1997 roku w kontekście zawieszenia biegu przedawnienia karalności takich przestępstw. Nie powinno przy tym budzić wątpliwości, że samo pojęcie „zlecenia”, o którym mowa w tym przepisie, należy rozumieć analogicznie — choć nie tak samo — jak w przypadku regulacji art. 148a $\S 1$ k.k., abstrahując z jednej strony od szczególnych treści motywacyjnych po stronie przyjmującego zlecenie zabójstwa, które pozostaje w związku z korzyścią lub jej obietnicą, z drugiej natomiast - od niewątpliwie nasuwającego się na płaszczyźnie semantycznej skojarzenia „zlecenia”, o którym traktuje art. 44 Konstytucji RP, z ,poleceniem” w rozumieniu art. 18 § 1 k.k. za sprawą określonych relacji podporządkowania przyjmującego ,zlecenie” wobec funkcjonariusza publicznego.

8 Por. M. Marciniak, Problematyka przestępstw popetnianych na zlecenie, „Przegląd Sądowy” 2006, nr 2, s. 124 n.; Z. Lasocik, Zabójca zawodowy i na zlecenie, Kraków 2003.

9 Już przed bez mała dwiema dekadami w toku podejmowanych działań reformatorskich aktualna była kwestia wyodrębnienia tej postaci sprawstwa niewykonawczego z niesprawczej formy podżegania. W piśmiennictwie zachowanie sprawcy zleceniodawczego powszechnie uznawane jest za znacznie bardziej społecznie szkodliwe niż podżeganie za sprawą silniejszego oddziaływania na adresata pokusą osiągnięcia określonego rodzaju korzyści. Dostrzegano w nim swoistą „kwalifikowaną" postać podżegania (por. M. Marciniak, op. cit., s. 128-129). Ten kierunek argumentacji znajdował się w wypowiedziach uzasadniających wprowadzenie tej formy sprawstwa do ustawy karnej. Konstrukcja tak zwanego sprawstwa zleceniodawczego — będąca swoistą „lustrzaną”, a przy tym ogólną postacią omawianego przyjęcia zlecenia zabójstwa - obejmowała zlecenie innej osobie wykonania jakiegokolwiek czynu zabronionego. W kolejnych projektach występowała w wariancie szerszym, obejmującym każdą postać zlecenia komu innemu popełnienia przestępstwa, oraz w wariancie węższym, odnoszącym się do zlecenia w zamian za udzieloną lub obiecaną korzyść majątkową lub osobistą. Por. projekt poselski nowelizacji kodeksu karnego, redakcja z 3 marca 2002 roku, druk nr 387, art. 17; sprawozdanie Podkomisji Nadzwyczajnej do rozpoznania projektów nowelizacji Kodeksu karnego z 4 października 2004 roku, druk sejmowy nr 2696; projekt zmian kodeksu karnego przygotowany przez Ministerstwo Sprawiedliwości, redakcja z 23 listopada 2006 roku, druk sejmowy $\mathrm{nr}$ 1756, art. $18 \S 1 \mathrm{a} ; \mathrm{M}$. Bielski, Sprawstwo zleceniodawcze w projekcie nowelizacji kodeksu karnego, „Prokuratura i Prawo” 2006, nr 10, s. 46 n.; M. Marciniak, op. cit.; Ł. Pohl, Sprawstwo zleceniodawcze jako nowa zjawiskowa forma czynu zabronionego. Uwagi na tle projektu 
Należy zauważyć, że próby typizacji przestępstwa przyjęcia zlecenia zabójstwa w systemie polskiego prawa karnego podejmowane były już wcześniej. Przepis art. 148a w identycznym brzmieniu przewidywał między innymi projekt nowelizacji kodeksu karnego w wersji z 23 listopada 2006 roku. Przestępstwo to było też zagrożone identyczną sankcją. W uzasadnieniu wspomnianego projektu — wyraziściej niż w motywach najnowszej zmiany — podkreślone zostały związki takich zamachów z przestępczością zorganizowaną. Jak wprost wskazywano:

rację wprowadzenia nowego typu karalnego bezprawia stanowi potrzeba podniesienia efektywności zwalczania czynów popełnianych w ramach działalności zorganizowanych struktur przestępczych, w tym coraz częściej występującego zjawiska eliminowania członków grup konkurencyjnych, świadków czy też innych niewygodnych osób.

\section{Projektowane rozwiązanie, jak dalej argumentowano:}

miało w istotnym stopniu przeciwdziałać mechanizmom rozpowszechniania się wyspecjalizowanego rodzaju przestępczości, ukierunkowanego na realizację czynów objętych takim zleceniem, tworząc poprzez kryminalizację czynności o charakterze sui generis przygotowawczym cenny mechanizm oddziaływania prewencyjnego na tym polu ${ }^{10}$.

Typizacja „odpłatnego” przyjęcia zlecenia zabójstwa z art. 148a § 1 k.k. niewątpliwie wyraża deklarowany przez projektodawcę zamysł wzmożenia ochrony życia człowieka. Przesuwa ochronę tego dobra prawnego w bardzo odległe od jego naruszenia przestrzenie zachowania sprawcy, do fazy głębokiego przeddokonania, ściślej - nie tylko na przedpole usiłowania, ale i penalizowanego w art. 148 $\S 5$ k.k. przygotowania zabójstwa ${ }^{11}$. Tworzy tym samym rodzaj „ochrony buforowej" tego dobra.

Kryminalizacja zachowań tak odległych od umyślnego spowodowania skutku śmiertelnego opiera się na kryminalnopolitycznie motywowanej konieczności jego ochrony, zanim jeszcze dojdzie do widomych oznak przygotowania zamachu,

zmian kodeksu karnego, „Ruch Prawniczy, Ekonomiczny i Socjologiczny” 2007, nr 3; wyrok SN z 3 kwietnia 2006 roku, sygn. V KK 316/05, OSNKW 2006, nr 5, poz. 52.

${ }^{10}$ Uzasadnienie projektu nowelizacji kodeksu karnego w wersji z 23 listopada 2006 roku, druk sejmowy nr 1756.

11 Warto w tym miejscu wspomnieć, iż skutkiem typizacji przyjęcia zlecenia zabójstwa z art. 148a $§ 1$ k.k. jest także zmiana w zakresie obowiązku wynikającego z art. $240 \S 1$ k.k. W znowelizowanej wersji przepis ten kryminalizuje nie tylko — jak dotąd — zaniechanie tego, kto mając wiarygodną wiadomość o karalnym przygotowaniu albo usiłowaniu lub dokonaniu zabójstwa w rozumieniu art. 148 k.k., niezwłocznie nie zawiadamia organu powołanego do ścigania przestępstw o popełnieniu tego przestępstwa, lecz także tego, kto w analogicznych warunkach nie zawiadamia o przestępstwie przyjęcia zlecenia zabójstwa stypizowanego w art. 148a k.k. 
przy założeniu istotnego prawdopodobieństwa wejścia przyjmującego zlecenie na wyższe poziomy narażenia lub naruszenia tego dobra prawnego. Regulacja ta może rodzić pytanie, czy przesunięcie karalności na przedpole przygotowania zabójstwa z perspektywy gwarancyjnych reguł prawa karnego nie sięga nazbyt głęboko w sferę zachowań potencjalnie niebezpiecznych dla życia ludzkiego. W ujęciu tego przepisu karalne jest bowiem przyjęcie zlecenia popełnienia zabójstwa wynikające — jak można założyć — z zadeklarowanej przez sprawcę samej „gotowości” realizacji tego czynu. Przestępstwo przyjęcia zlecenia zabójstwa w ujęciu art. 148a $\S 1$ k.k. jest wszakże formą urzeczywistnienia znamion czynu zabronionego, polegającą $\mathrm{w}$ istocie rzeczy na samym postanowieniu zabicia człowieka, ściślej zaś - podjęciu zamiaru popełnienia zabójstwa, stymulowanego udzieloną korzyścią lub jej obietnicą. Przyjęcie zlecenia zabójstwa staje się tym samym najwcześniejszym etapem stadialnym realizacji znamion przestępstwa umyślnego. Powstaje jednak wątpliwość, czy tak ujęty „etap stadialny” jest już „formą stadialną" czynu zabronionego — pojęć tych wszakże nie można utożsamiać - samo przyjęcie zlecenia zabójstwa nie realizuje bowiem jeszcze znamion jego przygotowania. Gdyby tak było, regulacja art. 148a $\S 1$ k.k. w kontekście unormowań art. 148 § 5 k.k., przewidującego karalność przygotowania zabójstwa, byłaby całkowicie zbędna ${ }^{12}$.

Zwracając uwagę na wątpliwości, jakie rodzi taki kształt „litery prawa”, nie można jednocześnie tracić z pola widzenia tych, które mogą powstać na płaszczyźnie tak ujętego prawa „w akcji”. Typizacja „odpłatnego” przyjęcia zlecenia zabójstwa w praktyce orzeczniczej może rodzić znaczne ryzyko powstania nieusuwalnych trudności z dowodzeniem realizacji znamion tego przestępstwa, która — w rzeczy samej — następuje w sferze przeżyć intelektualnych i wolicjonalnych. Już w toku prac nad projektem kodeksu karnego ten nowy typ przestępstwa spotkał się z przejawami krytyki, zarówno środowiska nauki prawa karnego, jak i praktyki wymiaru sprawiedliwości, wyrażanej w licznych opiniach dotyczących projektowanych rozwiązań. To, co w zamyśle autorów tego rozwiązania miało stanowić o jego wartości, zostało zakwestionowane i zinterpretowane jako forma rozszerzenia odpowiedzialności karnej na stany faktyczne polegające na nieujawnionej w żaden sposób decyzji o popełnieniu zabójstwa. Spośród kontrowersji, jakie - nie bez racji — wzbudziła ta propozycja, należy przywołać zwłaszcza

12 Nie powinno przy tym budzić wątpliwości, że za przygotowanie zabójstwa nie można uznać porozumienia między dającym a przyjmującym zlecenie zabójstwa, które można wyinterpretować ze znamion art. 148a $\S 1$ k.k. Wejście w porozumienie w ujęciu art. $16 \S 1$ k.k. należy bowiem interpretować jako układ integrujący współsprawców, a więc osoby mające wolę (zamiar) „wspólnego i w porozumieniu" popełnienia czynu zabronionego, nie zaś podżegającego (dającego zlecenie) i sprawcę (przyjmującego zlecenie), u którego zamiar popełnienia zabójstwa ma dopiero powstać, a taka sytuacja wynika z regulacji art. 148a $\S 1$ k.k. Porozumienie w ujęciu art. $16 \S 1$ k.k. dotyczy okoliczności niezbędnych do popełnienia przestępstwa, nie zaś kreowania samego zamiaru jego popełnienia, choć w praktyce rozróżnienie tych działań może być nierzadko bardzo kłopotliwe. Por. wyrok SA w Krakowie z 21 marca 2006 roku, sygn. II Aka 31/06, KZS 2006, z. 4 poz. 32. 
te, które wynikały z obaw środowiska karnistycznego o poszanowanie podstawowych zasad realizujących funkcję gwarancyjną prawa karnego, zwłaszcza zasady nullum crimen sine lege certa oraz nullum crimen sine actione, stanowiącej emanację ulpianowskiego pryncypium cogitationis poenam nemo patitur. Podnoszono także, na co zwrócono uwagę wcześniej, iż unormowanie to w pewnym zakresie dubluje wprowadzoną równocześnie regulację art. $148 \S 5$ k.k., przewidującą karalność przygotowania zabójstwa.

\section{IV}

Punktem wyjścia analizy ustawowych znamion nowego typu przestępstwa należy uczynić objaśnienie kluczowego w konstrukcji dyspozycji art. 148a $§ 1$ k.k. znamienia, jakim niewątpliwie jest ,zlecenie” popełnienia przestępstwa. Struktura przestępstwa odpłatnego przyjęcia zlecenia zabójstwa zakłada istnienie określonego układu między dwoma podmiotami, z których jeden zleca zabójstwo, udzielając jednocześnie korzyści majątkowej lub osobistej bądź składając obietnicę udzielenia korzyści o takim charakterze, drugi natomiast w zaistniałych okolicznościach i pod ich wpływem „przyjmuje zlecenie zabójstwa”. Zleceniodawca „za wynagrodzeniem" mobilizuje więc kogo innego, by w charakterze substytuta zrealizował jego zamiar — innymi słowy, „kupuje” egzekutora swojej woli, natomiast przyjmujący zlecenie zobowiązuje się do „odpłatnego” popełnienia zabójstwa w imieniu dającego takie zlecenie. Słowniki języka polskiego „zlecenie” definiują jako „polecenie wykonania czegoś”, względnie „,rodzaj umowy o świadczenie usług, w której zleceniobiorca zobowiązuje się do dokonania określonej czynności"13. Regulacja art. 148a $\S 1$ k.k., z racji użytego w przepisie znamienia czasownikowego, wywołuje wyraźne skojarzenia cywilistyczne. Zlecenie jako rodzaj umowy cywilnoprawnej unormowane jest $\mathrm{w}$ art. $734 \mathrm{i}$ n. k.c. Jego treścią jest zobowiązanie się przyjmującego zlecenie do odpłatnego lub nieodpłatnego dokonania określonej „czynności prawnej” dla dającego zlecenie i w jego imieniu. Przepisy dotyczące tej umowy stosuje się odpowiednio także do ,świadczenia usług”. Wspomniane intuicje cywilistyczne - co oczywiste - muszą być ograniczone do terminologii użytej w tej regulacji. Istota stosunku prawnego uregulowanego w kodeksie cywilnym zupełnie bowiem nie przystaje do bezprawnego czynu (,czynności bezprawnej”) stypizowanego w art. 148a $\S 1$ k.k. Nie można przy tym, wobec nasuwającego się prima facie skojarzenia, tracić z pola widzenia tego, że rzeczywistą treścią „umowy” między zlecającym a przyjmującym zlecenie zabójstwa jest osiągnięcie określonego skut$\mathrm{ku}$, a nie jedynie ,należyta staranność” zleceniobiorcy, by go osiągnąć, co w kategoriach przywołanych intuicji cywilistycznych bardziej przypomina umowę o dzieło za wynagrodzeniem (art. 627 k.c.), jako umowę rezultatu, niż umowę zlecenia.

13 Por. Stownik języka polskiego, t. 3, red. M. Szymczak, Warszawa 1989, s. 1025-1026. 
Uwzględniając wspomniane pierwiastki cywilistyczne, zlecenie zabójstwa musi być zatem rozumiane jako rodzaj swoistej „odpłatnej umowy” między dającym zlecenie (zleceniodawcą) a przyjmującym zlecenie zabójstwa (zleceniobiorcą), której essentialia negotii stanowi skutek w postaci śmierci człowieka.

\section{V}

Na tle znamienia czasownikowego ,przyjęcia zlecenia” znacznie mniej kontrowersji wzbudza użyte w omawianym przepisie pojęcie korzyści majątkowej, osobistej oraz ich obietnicy. Terminy te w części konkretyzuje wiążąca wykładnia autentyczna, w szerszym natomiast zakresie i na wyższym poziomie szczegółowości — utrwalony dorobek działań interpretacyjnych praktyki sądowej oraz dogmatyki prawa karnego. Korzyść majątkową lub osobistą w rozumieniu art. 148a § 1 k.k. należy rozumieć — zgodnie z legalną definicją zawartą w art. $115 \S 4$ k.k. — jako „korzyść zarówno dla siebie, jak i dla kogo innego”. To natomiast, co może być treścią tych korzyści, należy już do sfery wykładni niewiążącej. Analogicznie rzecz się ma z pojęciem „obietnicy” korzyści. W zakresie objaśniania zawartości treściowej tych pojęć z pomocą może przyjść bogaty dorobek wykładniczy powstały na gruncie obowiązujących przepisów kodeksowych ${ }^{14}$. Ogólnie rzecz biorąc, „korzyścią" w rozumieniu ustawy karnej jest jakiekolwiek dobro zdolne do zaspokajania potrzeb człowieka ${ }^{15}$. Pod pojęciem korzyści majątkowej należy z kolei rozumieć przysporzenie o materialnym charakterze - mające wartość ekonomiczną wyrażoną w określonej kwocie pieniężnej, choć nie musi mieć postaci pieniężnej, lecz formę darowizny rzeczowej — polegające na zwiększeniu aktywów, zmniejszeniu pasywów lub uniknięciu strat, a także każdą inną formę polepszenia sytuacji majątkowej ${ }^{16}$. Nie ma podstaw do przyjęcia zlecenia zabójstwa w rozumieniu art. 148a

14 Te dwie postaci korzyści występują w ustawie karnej zarówno jednocześnie — w relacji alternatywy - jak i pojedynczo, przy czym jako jedyna w ustawie pojawia się tylko korzyść majątkowa. Korzyści te mogą być przy tym udzielane (względnie przyjmowane) lub wyłącznie objęte obietnicą ich udzielenia (na przykład art. $115 \S 22$ pkt 6, art. 199 § 3, art. 228 § 1 i § 3-6, art. 229 § 1 i $\S 3-5$, art. $230 \S 1$, art. $230 \mathrm{a} \S 1$, art. $231 \S 2$, art. 250a $\S 1-2$, art. 264a $\S 1$, art. $271 \S 3$, art. 296a $\S 1-2)$. Pojęcie korzyść majątkowej, które w kodeksie karnym występuje częściej, pełni różne funkcje określone zarówno w części ogólnej (na przykład art. 33 § 3, art. 44a § 1-2, art. 45, art. 112 pkt 5, art. $115 \S 3$ k.k.), jak i w konstrukcji znamion typów czynów zabronionych, zwłaszcza, choć nie tylko, przeciwko działalności instytucji państwowych oraz samorządu terytorialnego, przeciwko mieniu lub przestępstw gospodarczych (na przykład art. $204 \S 1-2$, art. 211 a, art. 282, art. $286 \S 1$, art. $296 \S 2$, art. $299 \S 6$, art. $302 \S 2-3$, art. $305 \S 1$ k.k.), a także w unormowaniach części wojskowej (art. 327 § 2, art. 362 § 1 k.k.).

15 Por. wyrok SA w Lublinie z 17 kwietnia 2007 roku, sygn. II AKa 81/07, KZS 2007, nr 9, poz. 73.

16 Por. wyrok SN z 30 stycznia 1980 roku, sygn. VII KZP 41/78, OSNKW 1980, nr 3, poz. 2; wyrok SN z 21 sierpnia 2002 roku, sygn. III KK 230/02, Prok. i Pr. 2003, nr 3, poz. 12 i poz. 16; 
§ 1 k.k., gdy przyjmujący takie zlecenie w zamian za „korzyść majątkową” miał tytuł prawny do otrzymania od dającego zlecenie zabójstwa określonego świadczenia (na przykład zwrot lub obietnica zwrotu przez dającego zlecenie zabójstwa ,przedawnionej” pożyczki, której udzielił mu przyjmujący zlecenie) ${ }^{17}$. Korzyść osobista oznacza natomiast wszelkie „,dobra” niemające charakteru majątkowego, „dogodne dla przyjmującego lub zaspokajające jaką́ jego potrzebę", a więc każde przysporzenie niemajątkowe zwiększające psychiczne lub fizyczne „,poczucie komfortu” po stronie przyjmującego korzyść (na przykład awans zawodowy, nieodpłatne usługi seksualne, bilet na imprezę sportową lub kulturalną, przyznanie tytułu honorowego, nagrody niemajątkowej, ograniczenie zakresu obowiązków) ${ }^{18}$. Korzyść majątkowa lub osobista musi być obiektywnie odczuwana jako określony rodzaj przysporzenia budującego - pośrednio lub bezpośrednio - poczucie psychicznego dobrostanu, a więc stanu podwyższonego poziomu zadowolenia po stronie tego, kto je przyjmuje ${ }^{19}$. Tymczasem obietnica korzyści oznacza propozycję przysporzenia w przyszłości korzyści majątkowej lub osobistej sformułowaną w sposób uzasadniający oczekiwanie, iż zostanie ona spełniona. Forma i sposób jej udzielenia są dowolne ${ }^{20}$. Bez znaczenia dla realizacji znamion przestępstwa z art. 148a $\S 1$ k.k. jest to, kto jest beneficjentem udzielonej korzyści lub jej obietnicy — sprawca czy jakikolwiek inny podmiot. W przypadku obietnicy korzyści bez znaczenia jest także to, czy zleceniodawca miał rzeczywisty zamiar „wynagrodzenia” przyjmującego zlecenie, czy też wprowadził go w zakresie tej okoliczności w błąd. Istotne jest jedynie to, by przyjęcie zlecenia zabójstwa pozostawało w związku przyczynowym $\mathrm{z}$ ofertą udzielenia korzyści majątkowej bądź osobistej lub jej obietnicy przez zleceniodawcę.

Jak z poczynionych w tym kontekście uwag wynika, minimum realizacji znamion przestępstwa $\mathrm{z}$ art. $148 \S 1 \mathrm{a}$ k.k. jest obietnica co najmniej jednej z postaci korzyści wymienionej w dyspozycji tego przepisu. Zlecenie zabójstwa może być zatem przyjęte w zamian za traktowane alternatywnie: (1) korzyść majątkową, (2) korzyść osobistą, (3) obietnicę korzyści majątkowej, (4) obietnicę korzyści osobistej. Możliwe są jednak również rozmaite warianty krzyżowania się postaci

wyrok SN z 5 czerwca 2012 roku, sygn. II KK 287/11, Prok. i Pr. 2013, nr 1, poz. 4; wyrok SN z 8 listopada 2005 roku, sygn. WA 30/05, OSNwSK 2005, nr 1, poz. 2018.

17 Por. J. Majewski, [w:] Kodeks karny. Część ogólna. Komentarz, red. A. Zoll, t. 1, Warszawa 2007, s. 1185; wyrok SA we Wrocławiu z 24 maja 2012 roku, sygn. II AKa 87/12, Legalis nr 742364.

18 R. Góral, Kodeks karny. Praktyczny komentarz, Warszawa 2000, s. 306; A. Marek, Kodeks karny. Komentarz, Warszawa 2010, s. 312; J. Majewski, op. cit., s. 1186.

19 W razie wątpliwości, czy dana korzyść ma charakter majątkowy, czy osobisty — choć różnica ta nie ma wpływu na stosowanie omawianej podstawy odpowiedzialności karnej — należy przyjąć, że kryterium rozróżniającym jest to, czy w większym stopniu korzyść zaspokaja potrzebę materialną, czy niematerialną. W konkretnym wypadku niewątpliwe ustalenie tej okoliczności może być bardzo utrudnione. Por. A. Barczak-Oplustil, [w:] Kodeks karny. Część szczególna. Komentarz, red. A. Zoll, t. 2, Kraków 2006, s. 953; wyrok SA w Lublinie z 17 kwietnia 2007 roku, sygn. II AKa 81/07, KZS 2007, nr 9, poz. 73.

20 Por. wyrok SN z 5 listopada 1997 roku, sygn. V KKN 105/97, OSNKW 1998, nr 6, poz. 117. 
udzielonej bądź obiecanej korzyści majątkowej lub osobistej, a także formy łącznego ich występowania.

Przestępstwo stypizowane w art. 148a § 1 k.k. jest przestępstwem umyślnym, które można popełnić zarówno w zamiarze bezpośrednim, gdy sprawca zlecenie zabójstwa „chce” przyjąć, jak i w zamiarze ewentualnym, gdy jedynie „godzi się" na jego przyjęcie, akceptując warunki zaproponowane przez zleceniodawcę. Wiąże się to z tym, że jego warstwa intencyjna ma złożony, dychotomiczny charakter. $Z$ jednej strony odnosi się do umyślnego pozbawienia życia człowieka, z drugiej natomiast - do umyślnego przyjęcia określonej korzyści lub jej obietnicy, stanowiących ekwiwalent wykonanego zlecenia. W konsekwencji może mieć więc miejsce zarówno sytuacja, gdy sprawca przyjmuje zlecenie zabójstwa, „chceniem” obejmując korzyść lub jej obietnicę oferowaną w zamian, „godząc się" w tych warunkach na zabicie człowieka jako sposób czy warunek uzyskania określonych profitów, jak i taka, gdy sprawca będzie „chciał” śmierci ofiary, jednocześnie cum dolo eventuali akceptując przyjęcie przekazanej lub obiecanej korzyści, która in concreto nie ma dla niego decydującego znaczenia, będąc jedynie rodzajem „wartości dodanej”. Dla przypisania zamiaru realizacji znamion przyjęcia zlecenia zabójstwa bez znaczenia jest to, czy treścią zlecenia jest zabójstwo konkretnej osoby, czy też zabójstwo jakiegokolwiek — lub określonego według pewnych kryteriów i właściwości — „człowieka” (na przykład zabójstwo kogokolwiek dla pozyskania organów w celu transplantacji, zabójstwo członka określonego kręgu osób czy określonej społeczności). Na marginesie, mając na uwadze konstrukcję strony podmiotowej omawianego przestępstwa, warto zauważyć, iż na gruncie regulacji art. 148a § 1 k.k. — co koresponduje z wcześniej przywołaną wątpliwością co do spełnienia wymogu nullum crimen sine actione dochodzi do dość osobliwego przypadku „,zamiaru podjęcia zamiaru” popełnienia przestępstwa, który sam w sobie - jeśli jest stymulowany określoną w ustawie korzyścią lub jej obietnicą — realizuje znamiona przestępstwa.

Zważywszy na treść ustawowych znamion strony podmiotowej, typizacja przestępstwa odpłatnego przyjęcia zlecenia zabójstwa wpisuje się w formułowany w doktrynie już bez mała dwie dekady temu postulat normatywnego ujęcia przestępstwa zabójstwa „najemnego” popełnianego przez „płatnych morderców”21. Idzie przy tym znacznie dalej, przesuwając kryminalizację takich zachowań na etap bardzo odległy od realizacji znamion „zabijania najemnego”, w którejkolwiek spośród spenalizowanych dotąd postaci stadialnych zabójstwa. Przestępstwo

21 Por. K. Daszkiewicz, Przestępstwa przeciwko życiu i zdrowiu. Rozdział XIX Kodeksu karnego. Komentarz, Warszawa 2000, s. 83. 
to, jeżeli sprawca działał „w celu osiągnięcia korzyści majątkowej”, a więc gdy motywował przyjęcie zlecenia zabójstwa korzyścią majątkową lub jej obietnicą, spełni warunek podobieństwa w rozumieniu art. $115 \S 3$ k.k. do innych przestępstw „zyskownych” wraz z wynikającymi stąd na gruncie prawa karnego konsekwencjami (na przykład art. 64 § 1 k.k.). Nie ma natomiast podstaw do przyjęcia tak rozumianego podobieństwa w wypadku przyjęcia zlecenia zabójstwa, gdy było ono powiązane kauzalnie z udzieloną korzyścią lub obietnicą korzyści osobistej.

Treścią normy sankcjonowanej wynikającej z art. 148a $\S 1$ k.k. jest jedynie zakaz „odpłatnego” przyjmowania zlecenia zabójstwa, którego wyrazem ma być powstanie zamiaru jego popełnienia. Poza zakresem tej normy pozostają natomiast wszelkie formy „nieodpłatnego” czy „nieekwiwalentnego” przyjęcia takiego zlecenia, a więc formy powzięcia zamiaru popełnienia zabójstwa niewywołanego lub co najmniej niewzmocnionego udzieleniem korzyści lub jej obietnicą. Nie powinno budzić wątpliwości, iż „zlecenie" — odwołując się na zasadzie intuicji do standardów cywilistycznych — może zarówno mieć charakter „odpłatny”, a więc może być wykonane za wynagrodzeniem, które w tym przypadku stanowi jedna ze wskazanych w tym przepisie form korzyści, względnie ich obietnica, jak i być realizowane ,pod tytułem darmym”. Użycie w konstrukcji dyspozycji tego przestępstwa znamienia „W zamian” nie może być jednak odczytane inaczej jak w ten sposób, że czynnik uzyskanej lub obiecanej „korzyści” warunkuje odpowiedzialność za to przestępstwo. Jeżeli więc zleceniodawca „zleci” komuś, z kim pozostaje w wieloletniej przyjaźni, zabicie człowieka, a ten całkowicie „,bezinteresownie", w imię łączących ich więzi emocjonalnych bądź też wspólnej niechęci do przyszłej ofiary albo nawet z powodów nieustalonych w postępowaniu karnym, zlecenie takie przyjmie, nie wkraczając w etap działań przygotowawczych - wówczas jego odpowiedzialność nastąpiłaby już na podstawie art. 148 $\S 5$ k.k. — jego „gotowość” popełnienia zabójstwa pozostanie poza zakresem normy sankcjonowanej wynikającej z art. 148a $\S 1$ k.k. Znamiona strony podmiotowej tego przestępstwa zostaną bowiem wyczerpane jedynie w części „,wolicjonalnej”, nie zaś „motywacyjnej”. Wobec zaistnienia w tym zakresie wątpliwości dowodowych, a więc gdy opierając się na materiale zebranym w sprawie, nie będzie możliwe ustalenie, czy zlecenie zabójstwa przyjęte zostało „w zamian za udzieloną lub obiecaną korzyść majątkową lub osobistą”, czy też nastąpiło to „pod tytułem darmym", na zasadzie in dubio pro reo będą one musiały być przyjęte na korzyść przyjmującego zlecenie. W takim przypadku wykluczyć należy bowiem możliwość choćby posiłkowego odwoływania się do wynikającego z art. 735 $\S 1$ k.c. domniemania odpłatności zlecenia, czyli wykonania go za „wynagrodzeniem", jeżeli ani z umowy, ani z okoliczności nie wynika, że przyjmujący zlecenie zobowiązał się wykonać je „bez wynagrodzenia”. Takiej procedurze kategorycznie sprzeciwia się wymóg określoności czynu zabronionego wynikający z zasady nullum crimen sine lege stricta. Nie będzie więc podstaw do ścigania tego, kto zlecenie przyjął bez „wynagrodzenia”, w myśl niezmiennie aktualnej 
w tym wypadku zasady cogitationis poenam nemo patitur, skoro powstały zamiar zabójstwa człowieka po stronie zleceniobiorcy nie został uzewnętrzniony co najmniej — zgodnie z treścią art. $16 \S 1$ k.k. w zw. z art. $148 \S 5$ k.k. — w podjęciu czynności mających stworzyć warunki do przedsięwzięcia czynu zmierzającego bezpośrednio do dokonania zabójstwa.

Rozumowanie to prowadzi prostą drogą do wniosku, że norma sankcjonowana, którą można wyprowadzić z przepisu art. 148a $\S 1$ k.k. zabrania nie tyle samego przyjmowania zlecenia zabójstwa - takie zachowanie w świetle konstrukcji znamion tego przepisu pozostaje niezmiennie zachowaniem "legalnym” — ile jedynie przyjmowania takiego zlecenia „odpłatnie”, w zamian za określony w przepisie rodzaj korzyści bądź choćby jej obietnicę, a więc określoną formę gratyfikacji lub nawet jedynie jej zapewnienie. Spośród zleceń zabójstwa ustawodawca skryminalizował zatem wyłącznie przyjęcie zlecenia „,za wynagrodzeniem”. W kontekście treści motywacyjnej przyjmującego zlecenie zasadna będzie w związku z tym teza, że norma sankcjonowana wynikająca $\mathrm{z}$ art. 148a $\S 1$ k.k. chroni życie człowieka tylko na przedpolu zabójstwa najemnego czy też ściślej„odpłatnego”. O tym, co jest karalnym przyjęciem zlecenia zabójstwa w rozumieniu art. 148a $\S 1$ k.k., decyduje więc wyłącznie warstwa motywacyjna, a nie wolicjonalna. Wynikająca $\mathrm{z}$ tej tezy dyferencjacja prawnokarnej oceny zrodzonego po stronie sprawcy „przyjmującego zlecenie zabójstwa” zamiaru jego popełnienia, w kontekście deklarowanego przez autorów nowelizacji założenia, że miała ona na celu ogólne zintensyfikowanie ochrony podstawowych dóbr osobistych człowieka, wydaje się dość kontrowersyjna.

Konstrukcja znamion strony podmiotowej przestępstwa stypizowanego w art. 148a $\S 1$ k.k. istotnie wpływa także na zakres normy sankcjonowanej wynikającej z tego przepisu. Skoro realizuje je jedynie przyjęcie ,zlecenia zabójstwa człowieka w zamian za udzieloną lub obiecaną korzyść majątkową lub osobistą", nie powinno budzić wątpliwości, iż „zabójstwo człowieka” stanowiące treść przyjętego zlecenia należy rozumieć wyłącznie jako zabójstwo w typie podstawowym (art. 148 § 1 k.k.) lub jednym z typów kwalifikowanych określonych w art. 148 § lub $\S 3$ k.k., choć z przepisu - w przeciwieństwie do regulacji art. $148 \S 5$ k.k. — ograniczenie takie nie wynika wprost. Ze względu jednak na treść intencjonalną, wymaganą konstrukcją uprzywilejowanych odmian przestępstwa zabójstwa, pojęciowo niemożliwe jest przyjęcie zlecenia zabójstwa stymulowanego udzieloną korzyścią lub jej obietnicą, które mogłoby być jednocześnie popełnione pod wpływem silnego wzburzenia usprawiedliwionego okolicznościami (art. 148 § 4 k.k.), w warunkach współczucia, przy jednoczesnym żądaniu pozbawienia życia pochodzącego od pokrzywdzonego (art. 150 § 1 k.k.), czy wreszcie zabójstwa rodzącego się dziecka przez jego matkę pod wpływem przebiegu porodu (art. 149 k.k.). Są to „konkurencyjne” stany strony podmiotowej, których w kontekście subiektywnych znamion tych przestępstw nie da się pogodzić czy też zintegrować w ramach jednego zachowania. 
Sprawcą przestępstwa przyjęcia zlecenia może być każdy, kto spełnia ogólne warunki odpowiedzialności karnej. Jest to więc przestępstwo powszechne. Ustawa nie wymaga, by podmiotem tego przestępstwa był sprawca ,zawodowy" (professional killer), dla którego wykonanie tego rodzaju „zleceń” jest stałym źródłem dochodu, choć - jak można założyć — intencją ustawodawcy było wymierzenie omawianej regulacji zwłaszcza w sprawców profesjonalnie uprawiających taki proceder. Ujawnienie tej okoliczności, na ogólnych zasadach, aktualizowałoby dyrektywę nadzwyczajnego wymiaru kary z art. $65 \S 1$ k.k. Odpowiedzialności na podstawie art. 148a $\S 1$ k.k. nie poniesie sprawca nieletni, który w chwili czynu ukończył lat 15. Przepis art. $10 \S 2$ k.k. przewiduje możliwość pociągnięcia takiego sprawcy jedynie do odpowiedzialności karnej za zabójstwo określone w art. $148 \S 1-3$ k.k., nie zaś za przyjęcie zlecenia popełnienia takiego przestępstwa. Na marginesie warto dodać, iż nie będzie także podstaw do pociągnięcia takiego sprawcy do odpowiedzialności za dalszy etap realizacji zamiaru przestępstwa jego przygotowanie — którego karalność przewiduje art. 148 § k.k.

\section{VII}

Przyjęcie zlecenia zabójstwa w rozumieniu art. 148a $\S 1$ k.k. jest przestępstwem narażenia dobra prawnego na niebezpieczeństwo. Istota jego społecznej szkodliwości — jak można przeczytać w uzasadnieniu projektu — „sprowadza się do rozciągniętego w czasie zagrożenia dla dobra prawnego w postaci ludzkiego życia" 22 . Przestępstwo to jest występkiem abstrakcyjnego (potencjalnego) narażenia życia człowieka. Znamiona przepisu określają bowiem jedynie kryminalizowany sposób zachowania sprawcy — przyjęcie zlecenia zabójstwa w zamian za określone w dyspozycji profity lub ich obietnicę — nie wskazują natomiast wprost ani charakteru, ani skali tego niebezpieczeństwa. Nie jest to więc przestępstwo, które musi prowadzić do bezpośredniego, a nawet ,pewnego" niebezpieczeństwa naruszenia dobra, jakim jest życie człowieka. Niebezpieczeństwo tak rozumiane nie należy do jego znamion. W grę może w związku z tym wchodzić każde przyjęcie takiego zlecenia, nawet gdyby nie pociągało ono za sobą realnego niebezpieczeństwa zamachu na życie. Oznacza to, że nie musi być ono wykazywane w postępowaniu karnym jako warunek konieczny przypisania tego przestępstwa. Do jego dokonania nie jest zatem konieczne ustalenie, że przyjmujący zlecenie zabójstwa sprowadził jakiekolwiek niebezpieczeństwo dla życia człowieka. Realizacją jego znamion w tej formie jest już samo przyjęcie zlecenia zabójstwa wyrażające się w podjęciu zamiaru zabicia człowieka. Do odpowiedzialności karnej na podstawie art. 148a $\S 1$ k.k. — jak wspomniano - wystarczające jest wytworzenie jedynie potencjalnego niebezpieczeństwa naruszenia tego dobra.

${ }^{22}$ Uzasadnienie projektu nowelizacji kodeksu karnego — wersja z 5 kwietnia 2019 roku..., s. 24 . 
Przepis nie dostarcza podstaw do innej jego interpretacji, nawet jeśli taki właśnie był zamysł autorów tej regulacji. W tym kontekście można sformułować tezę — być może nieco ryzykowną, zważywszy na podmiotowy i przedmiotowy aspekt przyjęcia zlecenia zabójstwa — iż pewne strukturalne wątpliwości może budzić usytuowanie tego przepisu pośród przestępstw, których skutkiem jest śmierć człowieka. Wydaje się bowiem, że wobec odmiennego określenia znamion tego przestępstwa, wskazujących na inne uzasadnienie jego społecznej szkodliwości, z tej perspektywy lepszą lokalizacją omawianego przepisu byłaby być może ta, w której ustawa grupuje przestępstwa narażenia życia na niebezpieczeństwo. W regulacji tej nie chodzi wszakże o umyślne wywołanie skutku w postaci śmierci człowieka, lecz jedynie o umyślne wytworzenie dla życia człowieka niebezpieczeństwa wynikającego z samego powzięcia zamiaru naruszenia tego dobra. W kontekście postawionej tezy dodatkowe wątpliwości może jednak budzić porównanie poziomów karalności przestępstw „umyślnego narażenia życia” z art. 148 § 1a k.k. oraz art. $160 \S 1$ k.k., co do zasady rozłącznych, a zbieżnych jedynie w przedziale zagrożenia karą od 2 do 3, względnie do 5 lat pozbawienia wolności.

\section{VIII}

Przestępstwo przyjęcia zlecenia zabójstwa może być popełnione w każdej z form stadialnych, zarówno objętych karalnością - dokonanie lub usiłowanie przyjęcia zlecenia zabójstwa - jak i niekaralnych — przygotowanie przyjęcia takiego zlecenia. Stanowisku temu nie stoi na przeszkodzie to, iż przestępstwo to ma charakter przestępstwa narażenia abstrakcyjnego ${ }^{23}$. Można zatem w zamiarze przyjęcia zlecenia zabójstwa „przyjąć” takie zlecenie, można w takim samym zamiarze jedynie bezpośrednio zmierzać do jego przyjęcia, ale i w zamiarze bezpośrednim podejmować działania mające dopiero stworzyć warunki do bezpośredniego zmierzania do jego przyjęcia.

Dokonanie przyjęcia zlecenia zabójstwa, w kontekście brzmienia ustawowego znamienia czasownikowego „kto przyjmuje zlecenie” w zamian za określoną gratyfikację lub jej obietnicę, wiąże się z koniecznością zmian w sferze wolicjonalno-intelektualnej - będących swoistym skutkiem o charakterze intencjonalnym — polegających na powstaniu zamiaru popełnienia zabójstwa człowieka w rozumieniu art. 148 § 1-3 k.k. Musi on ujawniać się w stanowczym, kategorycznym, poważnym, ostatecznym i jednoznacznym postanowieniu popełnienia zabójstwa motywowanym - choć nie musi być to motywacja jedyna - udzieloną lub obiecaną korzyścią majątkową lub osobistą. Nie ulega wątpliwości, że z perspektywy procesowej powinności dowiedzenia realizacji skutku tego przestępstwa znacznie łatwiej będzie można wykazać transfer korzyści lub ich obietnicy niż ich wpływ

23 Por. Ł. Pohl, Prawo karne. Wyktad części ogólnej, Warszawa 2019, s. 204. 
na zmiany w sferze decyzyjnej (wolicjonalnej) po stronie tego, kto je przyjmuje. Bez znaczenia dla oceny zachowania przyjmującego zlecenie zabójstwa jako dokonania jest natomiast to, czy złożone przez przyjmującego zlecenie oświadczenie o jego przyjęciu do zleceniodawcy dotarło czy też nie. Decyduje o tym bowiem powstanie stanowczego zamiaru popełnienia zabójstwa, nie zaś stan wiedzy o tym fakcie po stronie dającego zlecenie.

Zgodnie z ogólną formułą art. 13 § 1 k.k. za usiłowanie przestępstwa przyjęcia zlecenia zabójstwa odpowiada z kolei ten, kto bezpośrednio zmierza do przyjęcia zlecenia, co jednak ostatecznie nie następuje. $Z$ oczywistych powodów nie można uznać za usiłowanie „przyjęcia zlecenia zabójstwa człowieka” samego złożenia takiej propozycji (oferty) przez dającego zlecenie, która przez adresata została bezwzględnie (bezwarunkowo) odrzucona. Usiłowane może być w takim przypadku jedynie zlecenie zabójstwa jako forma bezskutecznego podżegania do zabójstwa24. Przykładowo usiłowaniem popełnienia przyjęcia zlecenia zabójstwa będzie samo rozpoczęcie i prowadzenie negocjacji (rokowań) między stronami — zleceniodawcą (podżegającym) a adresatem oferty — co do warunków zlecenia, zanim dojdzie między nimi do uzyskania konsensusu. Usiłowaniem przyjęcia zlecenia zabójstwa może być także jego odrzucenie, na przykład z powodu zbyt mało atrakcyjnych warunków udzielonej lub obiecanej korzyści majątkowej lub osobistej bądź wygórowanych oczekiwań zleceniobiorcy. Sprawca w takim przypadku chciał bowiem przyjąć zlecenie i bezpośrednio do jego przyjęcia zmierzał, co jednak nie nastąpiło z powodu niewystarczającej „,siły argumentów” zlecającego. Za bezpośrednie zmierzanie do przyjęcia zlecenia zabójstwa należałoby uznać także wszelkie inne formy ujawnienia (uzewnętrznienia) gotowości do przyjęcia zlecenia zabójstwa w zamian za udzieloną korzyść majątkową lub osobistą albo ich obietnicę, zwłaszcza wobec osób, co do których chcący przyjąć zlecenie zabójstwa zakłada, iż noszą się one z zamiarem zabójstwa człowieka.

Wątpliwości może natomiast budzić kwestia, czy za usiłowanie popełnienia tego przestępstwa można uznać zachowanie polegające na „zastanowieniu się" nad złożoną propozycją „odpłatnego” popełnienia zabójstwa. Jak się wydaje, trudno przyjąć, by sam stan namysłu czy refleksji nad ofertą zabójstwa człowieka pochodzącą od dającego zlecenie, którego wynik, jako wyraz aktu woli, jest niepewny, stanowił bezpośrednie zmierzanie do jej przyjęcia. Do przypisania usiłowania niezbędne jest bowiem istnienie zamiaru przyjęcia zlecenia zabójstwa, a w tym wypadku stan taki nie zachodzi.

Wreszcie niekaralnym przygotowaniem przyjęcia zlecenia zabójstwa jest zgodnie z formułą art. $16 \S 1$ k.k. — zarówno wejście w porozumienie z inną

24 Por. uchwała SN z 21 października 2003 roku, sygn. I KZP 11/03, OSNKW 2003, nr 11-12, poz. 89. Przyjęcie usiłowanego podżegania możliwe będzie rzecz jasna jedynie w razie akceptacji koncepcji materialnego charakteru tej postaci zjawiskowej. Koncepcja formalnego charakteru tej postaci zjawiskowej takie zachowanie będzie bowiem sytuować w sferze dokonanego podżegania do zabójstwa. 
osobą (lub innymi osobami) w celu przyjęcia lub potencjalnego przyjęcia zlecenia zabójstwa, jak i pozostałe czynności wprost wskazane w tym przepisie bądź inne czynności „mające stworzyć warunki do przedsięwzięcia czynu zmierzającego bezpośrednio" do przyjęcia zlecenia zabójstwa.

\section{IX}

Przestępstwo przyjęcia zlecenia zabójstwa pozostaje w pozornym zbiegu przestępstw $\mathrm{z}$ realizacją znamion jednego $\mathrm{z}$ zabójstw stypizowanych $\mathrm{w}$ art. 148 $\S 1-3$ k.k. popełnionych w którejkolwiek z postaci stadialnych, w tym przygotowania zabójstwa (art. $148 \S 5$ k.k.). Wejście sprawcy przyjmującego „zlecenie zabójstwa" w dalszą, uzewnętrznioną fazę działań przeciwko życiu realizuje już inne postaci przestępstw przeciwko temu dobru. Jeżeli więc przyjmujący zlecenie zabójstwa - jako sprawca lub współsprawca — co najmniej pośrednio zmierza do jego dokonania, poniesie odpowiedzialność za zabójstwo w jednej z jego karalnych form stadialnych, adekwatnie do zaawansowania i efektu działań zmierzających do wywołania skutku w postaci śmierci człowieka. Dalsze czynności podjęte przez sprawcę przyjęcia zlecenia na drodze do realizacji skutku w postaci śmierci człowieka w rozumieniu art. $148 \S 1-3$ k.k. pochłoną więc znamiona przestępstwa $\mathrm{z}$ art. 148a $\S 1$ k.k. Przyjęcie zlecenia zabójstwa będzie wówczas przestępstwem współukaranym uprzednim.

Analogicznie należy ocenić następczą realizację przez przyjmującego zlecenie zabójstwa którejś z niesprawczych form realizacji zabójstwa. W tym kontekście analizowany może być przypadek „łańcuszkowego” zlecenia zabójstwa. Jeżeli więc przyjmujący zlecenie zabójstwa jego wykonanie zleci następnie odpłatnie lub nawet nieodpłatnie — komu innemu, którego w tym układzie można określić mianem „podwykonawcy” zlecenia, poniesie odpowiedzialność za podżeganie do zabójstwa, które pochłonie uprzednie przyjęcie zlecenia jego popełnienia jako przestępstwo współukarane. Za przyjęcie zlecenia zabójstwa nie będzie ponosił odpowiedzialności także ten, kto następnie współuczestniczył w realizacji znamion zabójstwa jako pomocnik. Warto na marginesie zwrócić uwagę, iż wejście przyjmującego zlecenie $\mathrm{w}$ dalszą fazę realizacji znamion zabójstwa $\mathrm{z}$ reguły będzie prowadziło do realizacji znamion zabójstwa „w wyniku motywacji zasługującej na szczególne potępienie" (art. 148 § 2 pkt 3). Zabójstwo najemne, popełnione w zamian za korzyść lub jej obietnicę, zwłaszcza jeśli chodzi o korzyść majątkową, z reguły będzie bowiem zasługiwać na ocenę skutkującą przypisaniem tej postaci miana zabójstwa kwalifikowanego. Przepis art. 148 § 2 pkt 3 k.k. może przy tym pozostawać $\mathrm{w}$ ewentualnym zbiegu kumulatywnym $\mathrm{z}$ innymi przepisami typizującymi kwalifikowane odmiany zabójstw. 
Wprowadzenie nowego typu przestępstwa przeciwko życiu z art. 148a § 1 k.k. istotnie zmienia sytuację prawną odpłatnie przyjmującego zlecenie zabójstwa, który dotąd, mimo powzięcia w warunkach „zlecenia” zamiaru jego popełnienia, pozostawał bezkarny aż do chwili wejścia w fazę usiłowania realizacji jego znamion. Zmiana wynikająca $\mathrm{z}$ wyodrębnienia przestępstwa przyjęcia zlecenia zabójstwa nie rzutuje natomiast na jakość odpowiedzialności tego, kto zleca popełnienie tego przestępstwa. Odpowiedzialność podmiotu udzielającego zlecenia w warunkach art. 148a $\S 1$ k.k. następuje niezmiennie w ramach jednej z niesprawczych form realizacji znamion typu czynu zabronionego. Tak jak w dotychczasowym stanie prawnym podstawę odpowiedzialności w takim przypadku z reguły będą stanowić unormowania art. $18 \S 2$ k.k. w zw. z art. 148 k.k. Konstrukcja tej formy popełnienia czynu zabronionego nie wymaga bowiem spełnienia żadnych dodatkowych warunków poza zamiarem bezpośrednim (dolus directus) wywołania po stronie adresata nakłaniania zamiaru popełnienia czynu zabronionego. Sposób jego wykreowania nie musi — choć może — być poparty dodatkowymi ,argumentami”, stymulantami czy zachętami. Nie ma wątpliwości, że pojemne treściowo pojęcie podżegania do popełnienia czynu zabronionego może polegać między innymi właśnie na „zleceniu" komu innemu jego wykonania, także w zamian za udzieloną lub obiecaną korzyść majątkową lub osobistą, chyba że zlecenie takie zostało skierowane do osoby, która miała już zamiar popełnienia zabójstwa, kiedy to znalazłaby zastosowanie konstrukcja pomocnictwa psychicznego ${ }^{25}$. W znowelizowanym stanie prawnym wobec niewyodrębnienia autonomicznej postaci sprawstwa zleceniodawczego, co radykalnie wpłynęłoby na zasady odpowiedzialności dającego zlecenie zabójstwa — jego odpowiedzialność będzie się więc opierać na identycznych zasadach jak dotychczas ${ }^{26}$. Jak uprzednio wspomniano, na ogólnych zasadach odpowiedzialność za podżeganie do zabójstwa poniesie także ten, kto przyjąwszy uprzednio zlecenie zabójstwa - w warunkach poszukiwania ,podwykonawcy” — nakłaniał do jego wykonania kogo innego. To, że podżeganie do zabójstwa motywowane było chęcią osiągnięcia korzyści, stanowiłoby w takiej sytuacji okoliczność z reguły uzasadniającą odpowiedzialność za kwalifikowany typ zabójstwa (art. 148 § 2 pkt 3 k.k.).

\section{XI}

W charakterze dopełnienia analizy przepisu art. 148a § 1 k.k. typizującego „odpłatne" przyjęcie zlecenia zabójstwa należy wspomnieć o zamieszczonej w kolej-

25 Por. wyrok SN z 3 kwietnia 2006 roku, sygn. V KK 316/05, OSNKW 2006, nr 5, poz. 52; P. Kardas, [w:] Kodeks karny. Część ogólna. Komentarz, t. 1, s. 307; M. Bielski, op. cit., s. 50.

26 Szerzej w tej kwestii zob. M. Bielski, op. cit., s. 52-55. 
nym paragrafie art. 148a k.k. ustawowej klauzuli niekaralności sprawcy zachowania określonego w $\S 1$, która aktualizuje się w wypadku, gdy przyjmujący zlecenie zabójstwa: (1) nie usiłował dokonać tego przestępstwa, (2) ujawniając jednocześnie wobec organu powołanego do ścigania przestępstw przed wszczęciem postępowania karnego osobę lub osoby zlecające zabójstwo oraz (3) istotne okoliczności popełnionego czynu. Spełnienie tych warunków sprawia, iż zachowanie sprawcy, mimo że narusza normę sankcjonowaną wynikającą z art. 148a $\S 1$ k.k., nie aktualizuje normy sankcjonującej wyprowadzanej z tego przepisu. Przepis art. 148a § 2 k.k., jak każda regulacja ustawowa przewidująca instytucję czynnego żalu, motywowany jest względami kryminalnopolitycznymi. Jak wynika z uzasadnienia projektu wskazującego jej ratio legis, taka postawa sprawcy ,pozwala na przyjęcie, że zdał on sobie sprawę z karygodności swego postępku i stopień szkodliwości takiego zachowania ulega tym samym istotnemu obniżeniu" 27 .

Abstrahując w tym miejscu od ewidentnej kontrowersyjności tak postawionej tezy odnoszącej się do wpływu zachowania sprawcy po popełnieniu czynu zabronionego na ocenę materialnego pierwiastka jego zachowania, należy zwrócić uwagę, iż analogiczną funkcję pełnią w ustawie karnej przepisy art. $229 \S 6$, art. 230a $\S 3$ k.k. czy art. 296a § 5, przy czym te, w odróżnieniu od regulacji art. 148a $\S 2$ k.k., w warunkach realizacji zbliżonych przesłanek gwarantują niepodleganie karze udzielającemu korzyści lub jej obietnicy, a nie temu, komu jest ona lub jej obietnica udzielana ${ }^{28}$. Zważywszy na zakres tematyczny i ramy niniejszego opracowania, a także rangę zasygnalizowanej kwestii oraz liczne wątpliwości, jakie wspomniany przepis i wynikające z niego przesłanki mogą wywoływać, problematyka czynnego żalu sprawcy przyjmującego odpłatnie zlecenie zabójstwa niewątpliwie wymaga odrębnego, szerszego opracowania.

\section{XII}

W nowym stanie prawnym zakres odpowiedzialności za umyślne zamachy przeciwko życiu został istotnie poszerzony nie tylko o zachowania realizujące znamiona przygotowania do popełnienia zabójstwa z art. 148 § 1-3 k.k. spenalizowanego w art. 148 § 5 k.k., lecz także o przypadek powzięcia zamiaru zabójstwa stymulowanego korzyścią majątkową lub osobistą albo obietnicą takich korzyści, realizujący znamiona nowego typu przestępstwa odpłatnego przyjęcia zlecenia zabójstwa $\mathrm{z}$ art. $148 \mathrm{a} \S 1$ k.k. Niezmiennie bezkarny pozostaje natomiast ten sprawca przyjmujący zlecenie zabójstwa, który uczynił to „pod tytułem darmym”,

27 Uzasadnienie projektu nowelizacji kodeksu karnego — wersja z 5 kwietnia 2019 roku..., s. 24 .

28 Nie tak daleko idące dobrodziejstwa zapewnia natomiast art. 250a $\S 4$ k.k., który w razie czynnego żalu sprawcy gwarantuje nadzwyczajne złagodzenie kary, z możliwością odstąpienia od jej wymierzenia. 
nie wychodząc poza sferę decyzji (zamiaru) o popełnieniu zabójstwa, a więc nie realizując co najmniej znamion karalnego po nowelizacji przygotowania (art. 148 $\S 5$ k.k.) ani też usiłowania zabójstwa. Kryminalizacja przyjęcia zlecenia zabójstwa jest $w$ istocie rzeczy rozwiązaniem fragmentarycznym i selektywnym. Konstrukcja ta odnosi się bowiem do jednego tylko rodzaju dobra prawnego. Nie kwestionując $\mathrm{w}$ tym kontekście zasadności wyboru życia ludzkiego — zważywszy na jego rangę i wartość - jako przedmiotu ochrony bezprecedensowego przestępstwa przyjęcia zlecenia naruszenia dobra prawnego, może nasunąć się pytanie, czy i inne dobra prawne, ze względu na swą społeczną istotność, nie zasługiwałyby na ochronę przed zamachami popełnionymi w takiej formie. Wątpliwość ta może prowadzić do kolejnego pytania, czy regulacja art. 148a $\S 1$ k.k. pozostanie rozwiązaniem jednostkowym, a więc jedynym ustawowym przypadkiem swoistego „przestępstwa zleceniobiorczego”, czy też — co może bardziej niepokoić — typ ten zainicjuje nową tendencję legislacyjną w kierunku poszerzenia przestrzeni kryminalizacji przez tworzenie innych jeszcze przestępstw polegających na „przyjęciu zlecenia" popełnienia określonych czynów zabronionych — zwłaszcza zaś tych, które w praktyce częściej niż inne mają charakter „najemny” — stając się początkiem „,serii” nowych typów „,przestępstw zleceniobiorczych”. W kontekście poczynionych uwag i dostrzeganych tendencji legislacyjnych nie można wreszcie wykluczyć i takiego scenariusza - mogącego niepokoić w najwyższym stopniu, jeśli miałby on wymiar inny niż jedynie czysto teoretyczny — w którym przyjęcie zlecenia popełnienia czynu zabronionego stałoby się kolejną, usytuowaną na przedpolu przygotowania, ogólną formą stadialną realizacji znamion czynu zabronionego, także w wypadku gdy byłaby ona karalna tylko wtedy, ,gdy ustawa tak stanowi".

Ogólnie rzecz biorąc wydaje się, iż przyjęte w zakresie ochrony życia zmiany — w tym typizacja przestępstwa przyjęcia zlecenia zabójstwa — są wyrazem swoistego ,przereagowania” ustawodawcy w sytuacji braku rzeczywistego uzasadnienia tak radykalnego zwiększenia surowości karania, nieznajdującego oparcia ani w argumentacji kryminologicznej, ani w danych statystycznych. Dominującym nurtem uzasadniania wprowadzonych zmian zdaje się w tym przypadku nurt argumentacji emocjonalnej odwołującej się do prewencji generalnej w jej aspekcie negatywnym. Podkreślany w uzasadnieniu projektu argument, iż ciężkie przestępstwa „budzą silną społeczną potrzebę odpłaty i napiętnowania”, przesuwa na plan dalszy, a w rzeczy samej pomija to, iż funkcja sprawiedliwościowej odpłaty musi być limitowana innymi funkcjami i celami prawa karnego. Kara nie może bowiem jedynie zaspokajać chęci społecznego odwetu czy zemsty, pozostając bezużyteczną na innych płaszczyznach jej utylitarnego racjonalizowania. 


\title{
THE CRIME OF ACCEPTING A MURDER BY ORDER (ARTICLE 148A § 1 OF THE CRIMINAL CODE) IN TERMS OF THE AMENDMENT TO THE PENAL CODE OF JUNE 13, 2019
}

\begin{abstract}
Summary
The study addresses the issues of the newly-introduced amendment to the Criminal Code of June 13, 2019. This refers to the he offense of accepting an order to commit murder for payment (Article 148a $\S 1$ of the Criminal Code). There is no doubt that this is an unprecedented solution, giving the principle of protection of life and its scope a completely new meaning. It derives the protection of life from the current framework of prohibited behavior protecting this good, moving it to the plane of behavior that has never been punishable before, very distant from the effect intended by the perpetrator. This crime, which has already been highlighted in the course of work on the amendment of criminal law in numerous opinions formulated by representatives of the carnivore environment, raises many doubts, including those that respect the statutory construction of the fundamental principles of criminal law. The criminalization of behavior on such a distant foreground of violation of a legal good may in particular be a source of controversy in the context of the guarantee function of criminal law. The purpose of the analysis is to draw attention to some of the most important issues regarding this crime, including its legal nature, the justification for its typing, the structure of its statutory features, possible coincidences or offenses it may remain in, the difficulties this new construction may pose for judicial practice, and the need to introduce the discussed "modification of borders" criminal protection of human life.
\end{abstract}

Keywords: assassination, protection of life, commission, material benefit, personal benefit, promise of benefit, criminalization, penalization, amendment

\section{BIBLIOGRAFIA}

\section{LITERATURA}

Bielski M., Sprawstwo zleceniodawcze w projekcie nowelizacji kodeksu karnego, „Prokuratura i Prawo" 2006, nr 10.

Daszkiewicz K., Przestęstwa przeciwko życiu i zdrowiu. Rozdział XIX Kodeksu karnego. Komentarz, Warszawa 2000.

Góral R., Kodeks karny. Praktyczny komentarz, Warszawa 2000.

Kodeks karny. Część ogólna. Komentarz, red. A. Zoll, t. 1, Warszawa 2007.

Kodeks karny. Część szczególna. Komentarz, red. A. Zoll, t. 2, Kraków 2006.

Lasocik Z., Zabójca zawodowy i na zlecenie, Kraków 2003.

Marciniak M., Problematyka przestępstw popetnianych na zlecenie, „Przegląd Sądowy” 2006, nr 2. Marek A., Kodeks karny. Komentarz, Warszawa 2010.

Pohl Ł., Prawo karne. Wykład części ogólnej, Warszawa 2019.

Pohl Ł., Sprawstwo zleceniodawcze jako nowa zjawiskowa forma czynu zabronionego. Uwagi na tle projektu zmian kodeksu karnego, ,Ruch Prawniczy, Ekonomiczny i Socjologiczny”2007, nr 3. Stownik języka polskiego, t. 3, red. M. Szymczak, Warszawa 1989. 


\section{ORZECZENIA SĄDOWE}

Uchwała SN z 21 października 2003 roku, sygn. I KZP 11/03, OSNKW 2003, nr 11-12, poz. 89. Wyrok SA w Krakowie z 21 marca 2006 roku, sygn. II Aka 31/06, KZS 2006, z. 4 poz. 32. Wyrok SA w Lublinie z 17 kwietnia 2007 roku, sygn. II AKa 81/07, KZS 2007, nr 9, poz. 73. Wyrok SA we Wrocławiu z 24 maja 2012 roku, sygn. II AKa 87/12, Legalis nr 742364. Wyrok SN z 30 stycznia 1980 roku, sygn. VII KZP 41/78, OSNKW 1980, nr 3, poz. 2. Wyrok SN z 5 listopada 1997 roku, sygn. V KKN 105/97, OSNKW 1998, nr 6, poz. 117. Wyrok SN z 21 sierpnia 2002 roku, sygn. III KK 230/02, Prok. i Pr. 2003, nr 3, poz. 12 i poz. 16. Wyrok SN z 8 listopada 2005 roku, sygn. WA 30/05, OSNwSK 2005, nr 1, poz. 2018. Wyrok SN z 3 kwietnia 2006 roku, sygn. V KK 316/05, OSNKW 2006, nr 5, poz. 52. Wyrok SN z 5 czerwca 2012 roku, sygn. II KK 287/11, Prok. i Pr. 2013, nr 1, poz. 4.

\section{INNE ŹRÓDŁA}

Projekt poselski nowelizacji kodeksu karnego, redakcja z 3 marca 2002 roku, druk nr 387.

Projekt zmian kodeksu karnego przygotowany przez Ministerstwo Sprawiedliwości, redakcja z 23 listopada 2006 roku, druk sejmowy nr 1756.

Sprawozdanie Podkomisji Nadzwyczajnej do rozpoznania projektów nowelizacji Kodeksu karnego z 4 października 2004 roku, druk sejmowy nr 2696.

Uzasadnienie projektu nowelizacji kodeksu karnego - wersja z 5 kwietnia 2019 roku, https:// legislacja.rcl.gov.pl (dostęp: 20.09.2019).

Uzasadnienie projektu nowelizacji kodeksu karnego w wersji z 23 listopada 2006 roku, druk sejmowy nr 1756. 